\title{
Effects of non-peptidal CCK receptor antagonist (L-364 718) on pancreatic responses to cholecystokinin, gastrin, bombesin, and meat feeding in dogs
}

\author{
S J KONTUREK, J TASLER, J W KONTUREK, M CIESZKOWSKI, \\ K SZEWCZYK, M HLADIJ, AND P S ANDERSON
}

From the Institute of Physiology, Academy of Medicine, Krakow, Poland and Department of Medicinal Chemistry, Merck Sharp and Dohme Research Laboratories, West Point, PA, USA

SUMmary Postprandial pancreatic secretion results from the interaction of neural and hormonal factors but their contribution to the net postprandial secretion is unknown. Recent description of highly specific and potent cholecystokinin (CCK) receptor antagonists allows the determination of the physiological role of $\mathrm{CCK}$ in the postprandial pancreatic secretion. In six dogs with chronic pancreatic fistulae, the blockade of CCK receptors by non-peptidal agent (L-364718) caused little change in basal pancreatic secretion, but decreased significantly $(p<0 \cdot 05)$ by about $60 \%$ the pancreatic protein response to meat feeding and virtually abolished the pancreatic responses to CCK-8 and bombesin. The pancreatic protein responses to pentagastrin, reaching about $37 \%$ of CCK maximum, was also significantly reduced but this effect was less pronounced than that observed in tests with CCK-8 or bombesin stimulation. In contrast, cholinergically stimulated pancreatic secretion, reaching about $40 \%$ of CCK maximum, was unaffected by L-364718. Cholecystokinin antagonism also failed to affect the postprandial and bombesin induced increments in plasma CCK and gastrin concentrations, but significantly reduced the PP responses to CCK-8 bombesin and meat feeding possibly as a result of the removal of the CCK mediated release of PP. We conclude that CCK plays a crucial role in the mediation of the postprandial and bombesin induced pancreatic secretion and in the PP release.

Although it is generally accepted that the pancreatic secretion is controlled by interacting neural and hormonal mechanisms, the controversy continues over the relative contribution of these mechanisms in interdigestive and postprandial secretion. ${ }^{12}$ The old suggestion that the reflex vagal cholinergic mechanisms play a considerable role in the postprandial pancreatic secretion ${ }^{2-4}$ has been undermined by recent evidence that antral gastrin ${ }^{56}$ and intestinal $\mathrm{CCK}^{7-9}$ may be also important physiological

Address for correspondence: Dr S J Konturek, Institute of Physiology, 31-531 Krakow, Grzegorzecka 16, Poland.

Accepted for publication 29 June 1988. mediators in the postprandial pancreatic secretion. The assessment of the hormonal contribution has been possible because of a recent description of highly specific and potent peptidal and non-peptidal CCK receptor antagonists ${ }^{10-12}$ which allow the pancreatic responses to be measured in the absence of the effect of CCK.

This study was undertaken to clarify the contribution of CCK and gastrin in the postprandial pancreatic secretion as well as in the pancreatic responses to exogenous hormonal peptides such as CCK-8, gastrin, and bombesin by using one of the most potent antagonists (L-364 718) of CCK receptors ${ }^{4-12}$ in conscious dogs with chronic gastric and pancreatic fistulae. 
Methods

Dogs

Studies in vivo were carried out on six mongrel dogs, weighing 18-20 kg, and prepared surgically with gastric (GF) and pancreatic fistulae (PF) as described before ${ }^{813}$ The studies reported here started about five months after surgery. Food was withheld for at least 18 hours before each test. Throughout all tests, except those with feeding, the GF was left open to allow for draining of gastric juice to the outside to prevent gastric acid from entering the duodenum and releasing endogenous hormones.

Secretions from the GF and PF were collected continuously and divided into 15 minute aliquots. The volume was recorded and acid concentration in the gastric juice and bicarbonate and protein concentrations in the pancreatic juice were measured in each sample and presented in 15 or 30 minute outputs.

Several tests were carried out in each animal. In tests with basal secretion, two hour collections were first obtained and then CCK receptor antagonist, L-364 718 (gift of Dr P S Anderson, Merck Sharp and Dohme Labs, West Point, PA) was injected intravenously in gradually increasing doses $(3 \cdot 5-240 \mu \mathrm{g} /$ $\mathrm{kg}$ ), each dose being given separately at a 30 minute interval and then increased by the factor of four. L-364 718 is 3S-(-)-N-(2,3-dihydro-1-methyl-2-oxo5-phenyl-1H-1, 4-benzodiazepine-3ry1)-1H-indole-2carboxamide (Fig. 1.).

In tests with meal induced secretion, each dog was offered $500 \mathrm{~g}$ of cooked homogenised ground beef for 15 minutes and this was usually completely consumed. Gastric and pancreatic collections were made for 60 minutes before, during, and 210 minutes after the feeding. When the postprandial secretory rate reached a well sustained plateau, L-364 718 was injected intravenously as a single bolus dose $(240 \mu \mathrm{g} /$ $\mathrm{kg}$ ) and then the secretion was examined for subsequent 150 minutes. In tests with exogenous hormonal stimulation, synthetic CCK octapeptide (CCK-8)

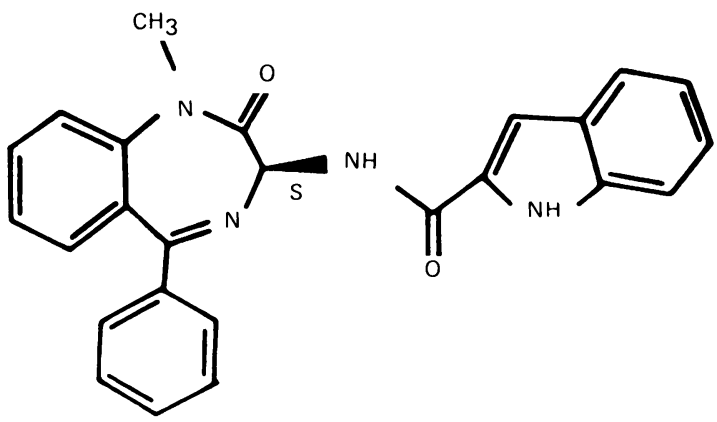

Fig. 1 Structure of L-364 718. (gift of Prof N Yanaihara, Shizuoka, Japan) was infused iv in a constant dose $(0.12 \mu \mathrm{g} / \mathrm{kg} / \mathrm{h})$ throughout the experiment to induce near maximal stimulation of pancreatic protein secretion in these dogs. When the secretory rate reached a plateau, L-364 718 was administered iv in gradually increasing doses (3.5-240 $\mu \mathrm{g} / \mathrm{kg}$ ), each injection being administered at 30 minute intervals during the same experiment. In control experiments, CCK-8 alone was administered in the same dose during the period of experimentation. For comparison, maximal pancreatic protein response to CCK-8 was determined in separate tests using a dose of $0.25 \mu \mathrm{g} / \mathrm{kg} / \mathrm{h}$. Pentagastrin (ICI, Macclesfield, UK) was infused iv in a constant dose (4 $\mu \mathrm{g} / \mathrm{kg} / \mathrm{h})$ and when the gastric acid and pancreatic protein secretion reached plateau, single bolus injections of L-364 718 were given at 30 minute intervals as in tests with CCK-8. In tests with bombesin (Farmitalia, Milano, Italy), the peptide was infused iv in a constant dose for 210 minutes and after 60 minutes of stabilisation of the secretory rate, L-364 718 was injected in gradually increasing doses at 30 minute intervals as in tests with caerulein.

In the tests involving administration of CCK-8, pentagastrin and bombesin, a solution of $0.5 \%$ albumin (Sigma Co, St Louis, MO) was used to dissolve these peptides in order to prevent their degradation and adsorption into the plastic tubes during intravenous infusion.

In tests with meat feeding and with infusion of CCK-8, bombesin, blood samples were taken from the peripheral vein at 15 to 30 minute intervals for radioimmunoassay of plasma gastrin and pancreatic polypeptide and for bioassay of CCK. Blood samples were collected in chilled tubes with $10 \mathrm{U}$ heparin and 400 U Kallikrein inhibitor, aprotonin (Trasylol) per millilitre and centrifuged, and the plasma was frozen within 15 minutes of sampling. The plasma gastrin concentration was determined using gastrin antiserum 4562 (gift of Prof J F Rehfeld, Aarhus, Denmark) and plasma PP was assayed using PP antiserum (gift of $\mathrm{Dr} \mathrm{R}$ E Chance, Eli-Lilly, Indianapolis, IN) as presented previously. ${ }^{13}$ Plasma CCK was determined by bioassay as described before..$^{14}$

Results are expressed as means (SE). In tests comparing various hormonal peptides and feeding with and without L-364718, the increments in pancreatic secretory outputs and plasma hormone concentrations were calculated and averaged to provide the incremental secretory outputs and incremental plasma hormone levels for the experimental period. The significance of the differences between means was evaluated using Student's $t$ test for paired values. Differences were considered significant if $p$ was less than $0 \cdot 05$. 
Table 1 Pancreatic $\mathrm{HCO}_{3}$ and protein outputs and plasma CCK, gastrin and PP concentrations in fasted dogs without and with iv injections of $L-364718$ in gradually increasing doses (3.5-240 $\mu \mathrm{g} / \mathrm{kg}$ ). Means (SE) of six tests on six dogs

\begin{tabular}{|c|c|c|c|c|c|}
\hline & \multicolumn{5}{|c|}{ Pancreatic Plasma } \\
\hline & $\begin{array}{l}\mathrm{HCO}_{3} \\
(\mu \mathrm{mol} / \\
15 \mathrm{~min})\end{array}$ & $\begin{array}{l}\text { Protein } \\
(\mathrm{mg} / \\
15 \mathrm{~min})\end{array}$ & $\begin{array}{l}\text { Gastrin } \\
(p M)\end{array}$ & $\begin{array}{l}C C K \\
(p M)\end{array}$ & $\begin{array}{l}P P \\
(p M)\end{array}$ \\
\hline Basal & $36(6)$ & $72(10)$ & $28(3)$ & $0 \cdot 8(0 \cdot 3)$ & $17(4)$ \\
\hline $\mathrm{L}-3647183.5 \mu \mathrm{g} / \mathrm{kg}$ & $39(7)$ & $102(22)$ & $32(4)$ & $0.7(0.2)$ & $12(4)$ \\
\hline $\mathrm{L}-36471815.0 \mu \mathrm{g} / \mathrm{kg}$ & $54(12)$ & $80(16)$ & $24(4)$ & $0.7(0.4)$ & $12(4)$ \\
\hline $\mathrm{L}-36471860 \cdot 0 \mu \mathrm{g} / \mathrm{kg}$ & $48(10)$ & $57(18)$ & $27(4)$ & $0.6(0.2)$ & $17(4)$ \\
\hline $\mathrm{L}-364718240.0 \mu \mathrm{g} / \mathrm{kg}$ & $44(12)$ & $32(10)^{*}$ & $24(6)$ & $0.6(0.4)$ & $12(2)$ \\
\hline
\end{tabular}

*Significant $(p<0.05)$ decrease below the basal value.

\section{Results}

EFFECTS OF L-364 718 ON BASAL PANCREATIC SECRETION

In fasted dogs, basal gastric acid secretion from the GF was negligible, while the pancreatic secretion showed some fluctuations in individual dogs. Protein outputs varied from about 15 to $250 \mathrm{mg} / 15$ minutes, averaging about 72 (10) $\mathrm{mg} / 15$ minutes during two hour basal collection period (Table 1$). \mathrm{HCO}_{3}$ output also fluctuated from about 32 (5) to 82 (14) $\mu \mathrm{mol} / 15$ minutes, averaging about 36 (6) $\mu \mathrm{mol} / 15$ minutes. Intravenous injections of L-364718 in doses of 3.5$240 \mu \mathrm{g} / \mathrm{kg}$ tended to reduce mean basal protein secretion but this was significant only at the highest dose of CCK-antagonist. No changes in basal gastrin, CCK or PP levels were observed after iv infusion of L-364 718 (Table 1).

\section{EFFECTS OF L-364 718 ON PANCREATIC} RESPONSES TO EXOGENOUS HORMONES Infusion of CCK-8 at $0.12 \mu \mathrm{g} / \mathrm{kg} / \mathrm{h}$ resulted in increase in pancreatic secretion that was reflected mainly in the protein outputs (Fig. 2) while the volume flow and $\mathrm{HCO}_{3}$ outputs showed only small increase. This dose of CCK-8 produced near maximal pancreatic protein secretion that in control experiments was well sustained for about 90 minutes but then tended to decline reaching at the end of experiment about $70 \%$ of the initial plateau. Maximal protein output achieved with CCK-8 at a dose of 0.25 $\mu \mathrm{g} / \mathrm{kg} / \mathrm{h}$ was 1240 (236) $\mathrm{mg} / 15$ minutes in these animals.

When L-364 718 was injected at 3.5 and $15 \mu \mathrm{g} / \mathrm{kg}$ there was a significant decrease in the protein output falling to the level not different from the basal protein secretion. After the highest doses ( 60 and $240 \mu \mathrm{g} / \mathrm{kg}$ ) of L-364718, protein output remained completely suppressed for the rest of the experiment (90
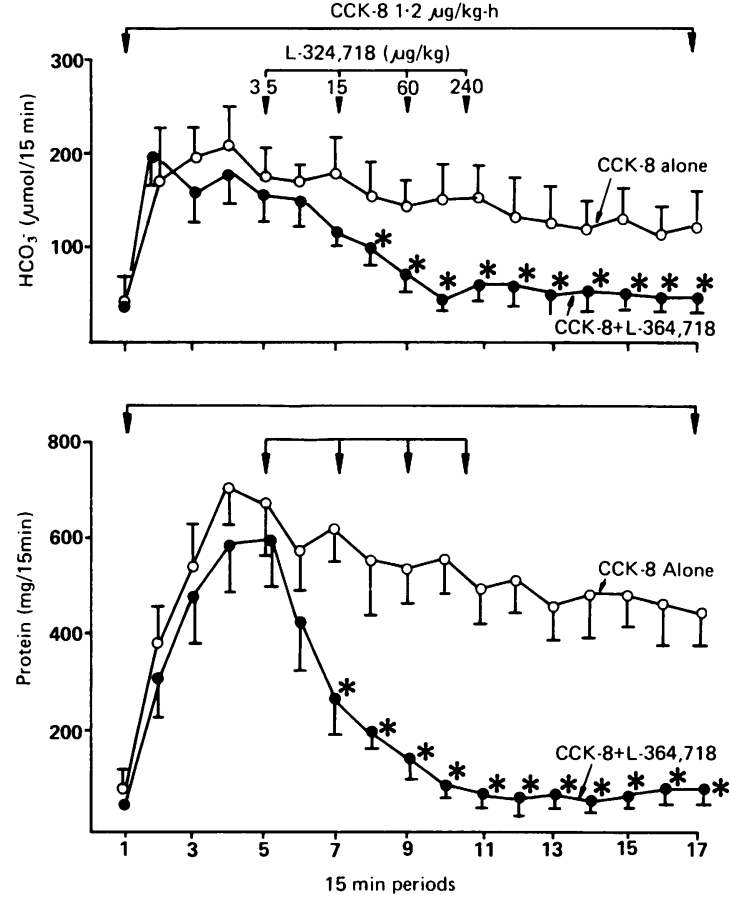

Fig. 2 Effects of L-364718 injected iv in gradually increasing doses on $C C K-8$ induced constant stimulation of pancreatic secretion. In control experiments, CCK-8 alone without $L-364718$ was infused for the time of experimentation. Mean (SE) of six experiments on six dogs with chronic gastric and pancreatic fistulae. *Indicates significant decrease below the control value.

minutes). Pancreatic $\mathrm{HCO}_{3}$ response to $\mathrm{CCK}-8$ was negligible but the administration of L-364718 also resulted in a significant reduction in this $\mathrm{HCO}_{3}$ response (Fig. 2).

Plasma gastrin concentrations were unchanged by iv infusion of CCK-8 with or without addition of L-364 718. Plasma CCK concentration rose from the basal value of $0.8(0.3) \mathrm{pM}$ to about $16.8(2.4) \mathrm{pM}$ during infusion of $\mathrm{CCK}-8$ and this was not significantly affected by administration of L-364 718. Plasma PP concentrations also showed a significant increment above basal level throughout the period of CCK-8 infusion. Treatment with L-364718 did not affect basal PP levels but reduced significantly the PP responses to CCK-8. At the dose of $240 \mu \mathrm{g} / \mathrm{kg}$ L-364 718, plasma level of PP was not different from the basal concentration (Table 2).

Pentagastrin infused iv in a constant dose $(4 \mu \mathrm{g} / \mathrm{kg} /$ h) resulted in a significant increase in gastric acid and pancreatic protein outputs (Figs 3 and 4). Gastric acid output reached the maximal observed outputs in 


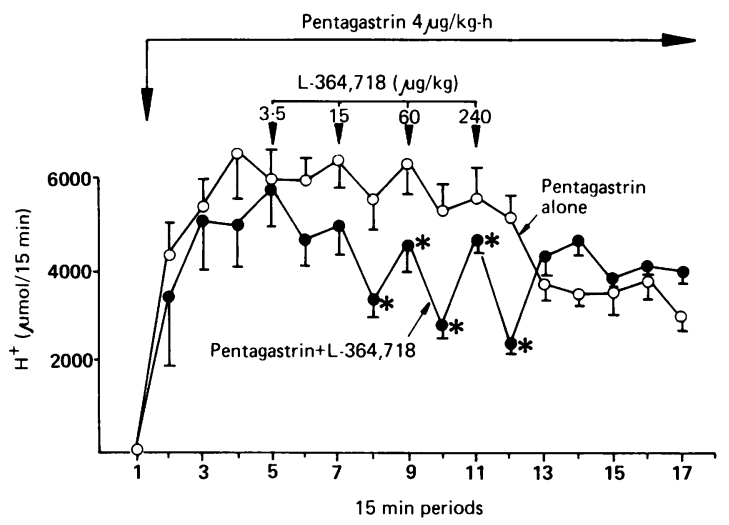

Fig. 3 Effects of L-364 718 injected iv in gradually increasing doses on pentagastrin induced constant stimulation of gastric acid secretion. In control experiments, pentagastrin alone without $L-364718$ was infused for the time of experimentation. Mean (SE) of six experiments on six dogs with gastric and pancreatic fistulae. *Indicates significant decrease below the control value.

these animals (8150 (1420) $\mu \mathrm{mol} / 30$ minutes), while pancreatic protein secretion attained only about $37 \%$ of the CCK maximum in these animals. Addition of L-364 718 to iv infusion, decreased gastric acid and pancreatic protein responses to pentagastrin. The decrease in gastric acid responses to pentagastrin occurred at all doses of L-364718 used and was
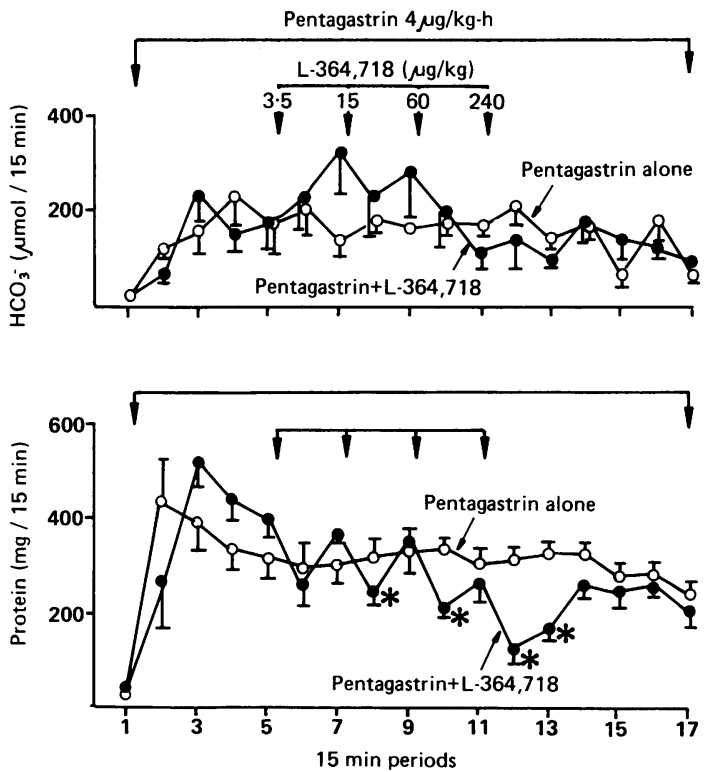

Fig. 4 Pancreatic bicarbonate and protein secretion in tests as in Figure 2.

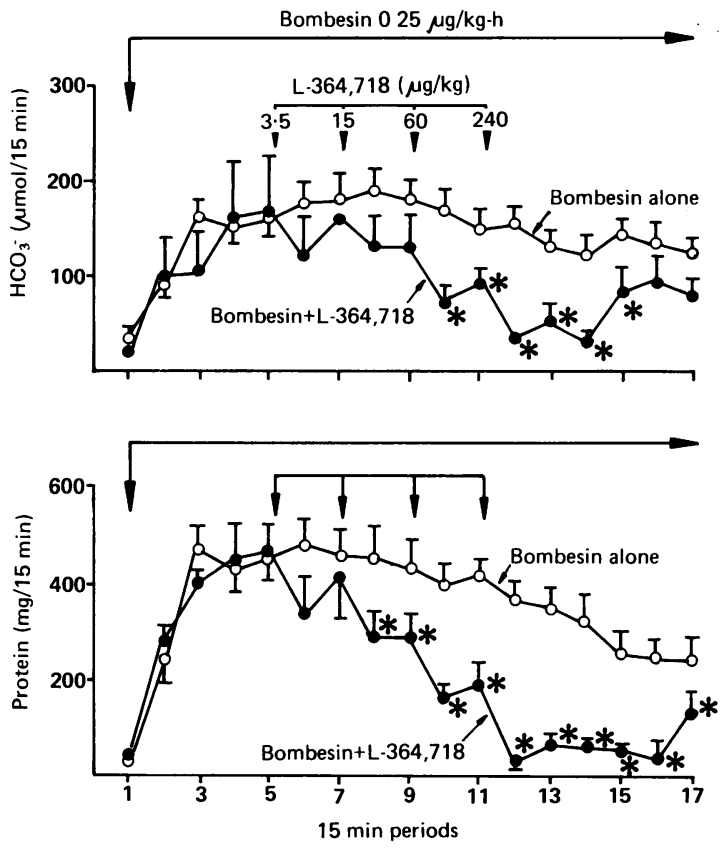

Fig. 5 Effects of L-364 718 injected iv in gradually increasing doses on bombesin-induced pancreatic bicarbonate and protein secretion. In control experiments bombesin alone without $L-364718$ was infused iv for the time of experimentation. Mean (SE) of six experiments on dogs with chronic gastric and pancreatic fistulae. ${ }^{*}$ Indicates significant decrease below the control value obtained with bombesin alone.

significant at a dose of $15 \mu \mathrm{g} / \mathrm{kg}$ and higher doses but even at the highest dose of L-364 718 $(240 \mu \mathrm{g} / \mathrm{kg})$ acid output was reduced only to about $50 \%$ of the control value obtained with pentagastrin alone. Pancreatic protein output in response to pentagastrin was relatively well sustained throughout the experimentation but when L-364 718 was added to iv infusion, there was a significant reduction in protein output. At the highest dose of L-364 718, the protein output was reduced to about $40 \%$ of the control value. After withdrawal of L-364718 administration, pancreatic protein returned to the control level within about a 30 minute period. Pancreatic $\mathrm{HCO}_{3}$ outputs in tests with pentagastrin was negligible and injections of L-364 718 failed to affect these outputs.

Bombesin infused iv in a constant dose of $0.25 \mu \mathrm{g} /$ $\mathrm{kg} / \mathrm{h}$ resulted in pancreatic protein secretory rate similar to that obtained with pentagastrin or reaching about $50 \%$ of CCK-8 maximum in these animals. In control tests, the secretory rate was relatively well sustained with only small decline at the end of experiment to about $70 \%$ of the initial peak value. 
Table 2 Plasma gastrin, CCK and PP concentrations in tests with iv infusion of CCK-8 $(0 \cdot 12 \mu \mathrm{g} / \mathrm{kg} / \mathrm{h})$ alone, bombesin $(0.25 \mu \mathrm{g} / \mathrm{kg} / \mathrm{h})$ alone or combined with iv injections of gradually increasing doses of L-364 718 (as in Figs 2 and 4) and after meat feeding alone and combined with iv injection of a single dose of L-364 718 (as in Fig. 5). In tests with $C C K-8$ and bombesin, plasma hormone levels are means (SE) of six tests on six dogs recorded during a 15 minute period after injection of $L-364718$ or during the corresponding periods of infusion of CCK-8 or bombesin alone. In tests with feeding, the plasma hormone concentrations are mean values (SE) of six tests on six dogs recorded (at 30 minute intervals) during first hour after injection of L-364 718 or during corresponding control postprandial hour without L-364718 administration.

\begin{tabular}{|c|c|c|c|}
\hline & $\begin{array}{l}\text { Gastrin } \\
(p M)\end{array}$ & $\begin{array}{l}C C K \\
(p M)\end{array}$ & $\begin{array}{l}P P \\
(p M)\end{array}$ \\
\hline Basal & $28(3)$ & $0 \cdot 8(0.3)$ & $14(3)$ \\
\hline $\begin{array}{l}\text { CCK-8 alone } \\
\text { CCK-8+L-364 3.5 } \mu \mathrm{g} / \mathrm{kg} \\
\text { CCK-8+L-364 15.0 } \mu \mathrm{g} / \mathrm{kg} \\
\text { CCK-8+L-364 60.0 } \mu \mathrm{g} / \mathrm{kg} \\
\text { CCK-8+L-364 240.0 } \mu \mathrm{g} / \mathrm{kg}\end{array}$ & $\begin{array}{l}24(4) \\
30(6) \\
23(4) \\
24(5) \\
28(6)\end{array}$ & $\begin{array}{l}16 \cdot 6(2 \cdot 8) \\
16 \cdot 4(2 \cdot 0) \\
17 \cdot 0(2 \cdot 4) \\
16 \cdot 8(3 \cdot 0) \\
16 \cdot 2(2 \cdot 2)\end{array}$ & $\begin{array}{l}76(12) \\
72(16) \\
62(12)^{*} \\
37(5)^{*} \\
18(4)^{*}\end{array}$ \\
\hline $\begin{array}{l}\text { Bombesin alone } \\
\text { Bombesin }+\mathrm{L}-3643.5 \mu \mathrm{g} / \mathrm{kg} \\
\text { Bombesin }+\mathrm{L}-36415 \cdot 0 \mu \mathrm{g} / \mathrm{kg} \\
\text { Bombesin }+\mathrm{L}-36460 \cdot 0 \mu \mathrm{g} / \mathrm{kg} \\
\text { Bombesin }+\mathrm{L}-364240 \cdot 0 \mu \mathrm{g} / \mathrm{kg}\end{array}$ & $\begin{array}{l}186(24) \\
211(34) \\
235(41) \\
229(36) \\
241(28)\end{array}$ & $\begin{array}{r}9 \cdot 2(1 \cdot 2) \\
10 \cdot 6(2 \cdot 6) \\
9 \cdot 8(1 \cdot 9) \\
11 \cdot 2(2 \cdot 2) \\
12 \cdot 2(2 \cdot 3)\end{array}$ & $\begin{array}{l}144(28) \\
154(27) \\
123(29) \\
79(18)^{*} \\
33(12)^{*}\end{array}$ \\
\hline $\begin{array}{l}\text { Meat feeding alone } \\
\text { Meat feeding }+\mathrm{L}-364240 \mu \mathrm{g} / \mathrm{kg}\end{array}$ & $\begin{array}{l}124(28) \\
136(31)\end{array}$ & $\begin{array}{l}6 \cdot 4(1 \cdot 2) \\
6 \cdot 1(1 \cdot 4)\end{array}$ & $\begin{array}{l}236(37) \\
94(14)^{*}\end{array}$ \\
\hline
\end{tabular}

*Significant $(\mathrm{p}<0.05)$ decrease below the control value.

NT $=$ not tested .

Injections of L-364 718 in gradually increasing doses resulted in a significant reduction in protein outputs at a dose of $15 \mu \mathrm{g} / \mathrm{kg}$. The protein secretory response to bombesin fell to the basal level at the highest dose $(240 \mu \mathrm{g} / \mathrm{kg})$ of CCK antagonist. After the last dose of L-364718, the protein secretion remained suppressed for the rest of the experiment. Pancreatic $\mathrm{HCO}_{3}$ secretion in response to bombesin was rather small and within the range observed in tests with CCK-8. Injections of L-364 718 in gradually increasing doses resulted in a significant reduction in $\mathrm{HCO}_{3}$ outputs starting with the dose of $60 \mu \mathrm{g} / \mathrm{kg}$. Bombesin resulted in a significant increase in plasma concentrations of CCK, gastrin and PP. The rise in plasma CCK, gastrin and PP averaged, respectively, 9.2 $(1 \cdot 2), 186(24)$, and 144 (28) pM. After iv injections of L-364 718 in gradually increasing doses, there was a dose dependent decrease in plasma PP concentrations falling at the dose of $250 \mu \mathrm{g} / \mathrm{kg}$ to the level not significantly different from control values. Plasma concentrations of CCK and gastrin remained virtually unchanged by increasing doses of L-364 718 (Table 2).
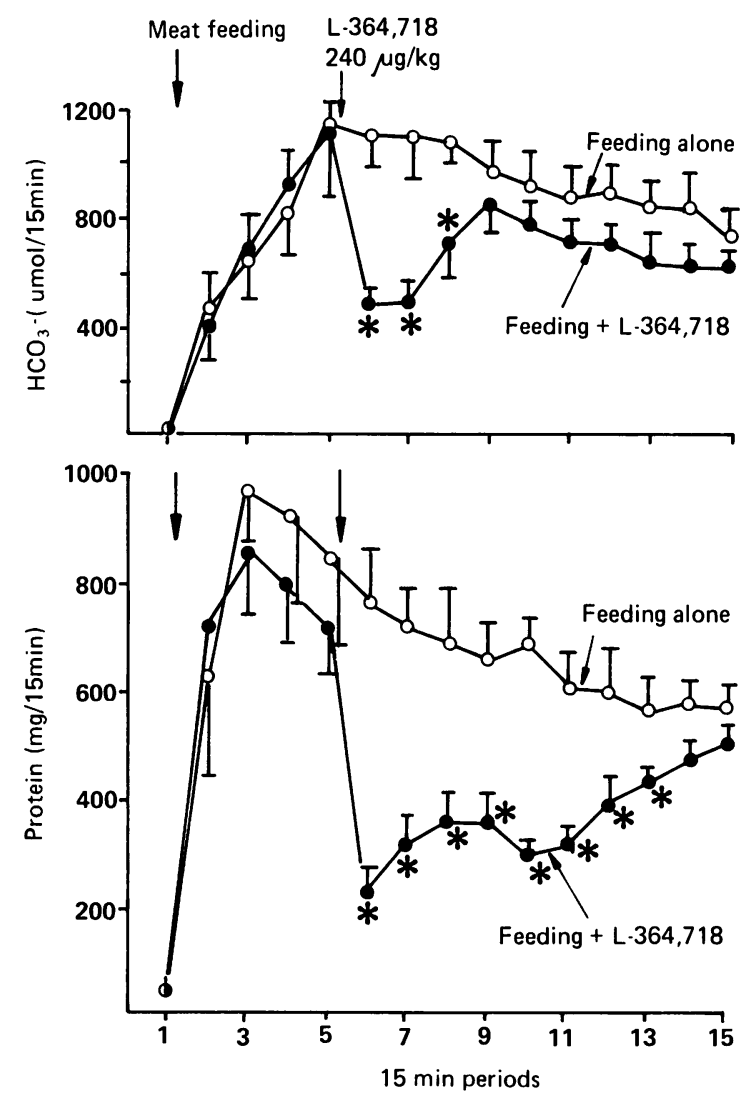

Fig. 6 Effects of single dose injection of L-364 718 on the postprandial pancreatic bicarbonate and protein outputs. In control tests, the postprandial pancreatic secretion was determined without administration of L-364 718. Mean (SE) of six tests on six pancreatic fistulae dogs. ${ }^{*}$ Indicates significant decrease below the control value obtained with meat feeding alone.

Bethanechol infused iv in a constant dose $(100 \mu \mathrm{g} /$ $\mathrm{kg} / \mathrm{h}$ ) resulted in a well sustained increase of pancreatic protein secretion reaching about $40 \%$ of CCK maximum. There was only small increase in pancreatic $\mathrm{HCO}_{3}$ secretion. L-364718 added to iv infusion in single bolus doses $(3 \cdot 5-240 \mu \mathrm{g} / \mathrm{kg})$ did not significantly affect gastric or pancreatic secretory rate and these results have been omitted for the sake of clarity.

EFFECTS OF L-364 718 ON PANCREATIC RESPONSES TO MEAT FEEDING

Meat feeding evoked an increase in pancreatic secretion of $\mathrm{HCO}_{3}$ and protein (Fig. 6), reaching respective peaks in the second and fourth 15 minute periods after feeding. Both parameters of pancreatic 
secretion tended to decline during the 210 minute postprandial period. L-364 $718(240 \mu \mathrm{g} / \mathrm{kg})$ given iv in a single bolus injection resulted in an immediate reduction in protein outputs falling within first 15 minute period to about $40 \%$ of the control value and remaining significantly reduced in the first and second postprandial hour. The $\mathrm{HCO}_{3}$ response was also significantly reduced by L-364 718 but only in the first hour after injection of L-364 718.

Plasma CCK and gastrin concentration showed a marked rise after feeding and L-364 718 did not affect significantly these levels (Table 2). Pancreatic protein also showed a marked increment that was well sustained throughout the control postprandial period. L-364 718 caused a marked reduction in the PP increment by about $70 \%$ throughout the postprandial period.

\section{Discussion}

This study provides an evidence that CCK receptors of the acinar cells play an important role in the stimulation of pancreatic protein secretion in response to ordinary meat feeding, gastrin, and bombesin but not in the basal secretion and after cholinergic stimulation.

Previous studies using proglumide, that was originally designed by Rovati et $a^{15}$ as gastrin receptor antagonist for the treatment of peptic ulcer, showed that this agent administered in conscious dogs in massive dose $(300 \mathrm{mg} / \mathrm{kg} / \mathrm{h})$ was also an effective inhibitor of the pancreatic responses to CCK-8 and duodenal perfusion with amino acids and fat but not bethanechol. ${ }^{16}$ The action of proglumide was specific for CCK but its widespread usefulness was limited because of its very low potency. A series of competitive non-peptide benzodiazepine antagonists of cholecystokinin were synthetised ${ }^{12}$ recently and the most potent L-364718, has been characterised as highly specific and long acting CCK antagonist in a variety of biological systems. ${ }^{12}$ It was found to be effective after oral and parenteral administration and exhibited the duration of action of two to three hours after a single iv dose administration. ${ }^{17}$ This CCK antagonist has been examined for biliary and pancreatic secretion in conscious dogs. ${ }^{18}$ When given orally it was found to inhibit the postprandial biliary secretion but, unexpectedly, failed to affect the postprandial pancreatic secretion despite its ability to antagonise the stimulatory action of exogenous CCK on this secretion. ${ }^{18}$

In this study we used L-364718 by intravenous injections in a dose range several times lower than that used in previous report ${ }^{18}$ and found to be highly effective in the inhibition of pancreatic secretion induced not only by caerulein but also by meat feeding and bombesin. The failure of L-364 718 to suppress the postprandial pancreatic secretion in previous report ${ }^{18}$ probably reflected an insufficient absorption of the drug after its intragastric administration rather than the lack of the involvement of CCK in this secretion. Indeed, our results provide a strong support for the notion that the pancreatic secretion induced by feeding and bombesin is mediated mainly by endogenous CCK. As the pancreatic response to bombesin can be completely blocked by L-364718 at a dose that also totally suppressed pancreatic response to CCK-8, it may be concluded that bombesin stimulation is predominantly mediated by endogenous CCK. The same dose of L-364718 reduced the postprandial pancreatic secretion by about $60 \%$ suggesting that CCK is the major but not the only factor involved in the secretory stimulation. As cholinergically stimulated pancreatic secretion is resistant to the inhibitory action of CCK antagonist, it is likely that cholinergic vagovagal reflexes originating in the stomach and the gut $^{19-22}$ are involved in the postprandial pancreatic secretion. Such cholinergic gastro- and enteropancreatic reflexes may augment the stimulatory effect of CCK and by themselves may contribute at least $50 \%$ to postprandial pancreatic secretion. ${ }^{22-24}$

This has been supported by several observations that vagotomy ${ }^{22} 25$ and atropine $\mathrm{e}^{22} 23$ reduced the secretory responses to meal stimuli only from the intact but not from denervated (autotransplanted) pancreas and that the pancreatic enzyme response to luminal stimulation had shorter latency compared with that to intraportal injection of CCK. ${ }^{23}$ Using specific radioimmunoassay to measure the postprandial plasma concentrations of CCK, we reported that CCK is released postprandially in sufficient amounts to drive the major portion of the postprandial pancreatic secretion. ${ }^{89}$ This study showing that CCK-antagonist eliminates about $60 \%$ of the postprandial protein secretion confirms and reinforces the key role of CCK in the gastrointestinal phase of pancreatic secretion. This does not exclude the contribution of other, particularly neural, mechanisms which seem to be activated mainly in the early postprandial period before the humoral mechanisms are fully activated. ${ }^{12}$

The crucial question raised by the use of CCK antagonists is whether these agents also interfere with the effects of gastrin on gastric acid and pancreatic secretion. Gastrin and CCK share a common $\mathrm{COOH}$-terminal pentapeptide amide, therefore, CCK agonists and antagonists should affect in a similar fashion the secretory activity of oxyntic cells and the acinar cells. Our present study shows that, unlike CCK, pentagastrin is only a partial agonist of pancreatic protein secretion. According to our 
results, pentagastrin used in the dose producing maximal gastric acid secretion, stimulated the pancreatic protein in conscious dogs only to about $37 \%$ of the CCK maximum and this is similar to that achieved by gastrin (G-17) used at a dose of $250 \mathrm{pmol} /$ $\mathrm{kg} / \mathrm{h} .{ }^{26}$ This indicates that pentagastrin, though a less potent stimulant than gastrin, mimics, at least in part, the effect of gastrin on the pancreatic secretion. The addition of CCK antagonist to pentagastrin infusion caused only partial inhibition of gastrin induced gastric acid and pancreatic protein secretion suggesting that pentagastrin induced gastropancreatic secretion is less sensitive to the action of our CCK receptor antagonist. This remains in agreement with previous observation $^{16}$ that proglumide, a prototype of CCK receptor antagonist, was an effective inhibitor of pentagastrin induced gastric acid secretion in dogs only when larger doses of this agent were used or when lower doses of pentagastrin were used for gastric acid stimulation. As in other systems L-364718 was found to be highly specific for CCK receptor having no effect on gastrin receptors, ${ }^{11}$ further studies with authentic G-17 and G-34 are needed to determine whether gastric acid and pancreatic protein responses to gastrin itself is sensitive to the inhibitory action of L-364 718. The fact that the spectrum of biological activity of pentagastrin is similar to gastrin suggests that L-364718 shows somewhat higher anti-CCK than antigastrin activity and that it is, therefore, more suitable for the study of CCK than gastrin in pancreatic physiology. The reason for the discrepancy in the action of CCK agonists and antagonists on gastric and pancreatic secretion in vivo is not apparent from our study but it may be because of the existence of two populations of CCK/gastrin receptors - that is, CCK preferring receptors and gastrin preferring receptors. The former receptors would predominate in the acinar cells and exhibit high affinity for CCK and its selective antagonists, while the latter receptors would predominate in the oxyntic cells and exhibit high affinity to gastrin but lower affinity to CCK and its antagonists. An alternative explanation would be that in vivo gastrin and CCK not only activate the $\mathrm{CCK} /$ gastrin receptors but also cause the release of local inhibitor of pancreatic and gastric secretion, respectively. Partial support for this notion is provided by recent observation that CCK is more potent than gastrin in releasing somatostatin from the gastric endocrine cells. ${ }^{27}$ Perhaps a similar inhibitor is released by gastrin in the pancreas but we have no support for such speculation.

\section{References}

1 Solomon TE. Regulation of pancreatic secretion. Clin Gastroenterol 1985; 13: 657-78.
2 Singer MV. Neurohormonal control of pancreatic enzyme secretion in animals. In: Go VLW, ed. The exocrine pancreas: biology, pathobiology and diseases. New York: Raven Press, 1986: 315-31.

3 Pavlov IP. The work of the digestive glands. London: Griffin, 1902.

4 Thomas JE. Mechanism of action of pancreatic stimuli studied by means of atropine-like drugs. Am J Physiol 1964; 206: 124-8.

5 Preshaw RM, Grossman MI. The mechanism of vagal stimulation of gastric acid secretion. Gastroenterology 1965; 48: 493-9.

6 Preshaw RM, Cooke AR, Grossman MI. Stimulation of pancreatic secretion by a humoral agent from the pyloric gland area of the stomach. Gastroenterology 1965; 49: 617-22.

7 Byrnes DJ, Henderson L, Borody T. Radioimmunoassay of cholecystokinin in human plasma. Clin Chim Acta 1981; 111: 81-9.

8 Konturek SJ, Tasler J, Bilski J, Lamers CB. Physiological role and localization of cholecystokinin release in dogs. Am J Physiol 1986; 250: G391-7.

9 Konturek SJ, Konturek JW, Lamers CB, Tasler J, Bilski $\mathrm{J}$. Role of secretin and CCK in the stimulation of pancreatic secretion in conscious dogs. Effects of atropine and somatostatin. Int J Pancreatol 1987; 2: 223 35.

10 Makovec T, Christe R, Bani M, Revel L, Setnikar I, Rovati AL. New glutamic and aspartic derivatives with potent CCK-antagonistic activity. Eur J Med Chem Chim Ther 1986; 21: 9-20.

11 Jensen RT, Zhou Z-C, Murphy RB, et al. Structural features of various proglumide-related cholecystokinin receptor antagonists. Am J Physiol 1986; 251: G839-46.

12 Chang RSL, Lotti VJ. Biochemical and pharmacological characteristics of an extremely potent and selective nonpeptide cholecystokinin receptor antagonist. Proc Natl Acad Sci USA 1986; 83: 4923-6.

13 Swierczek JS, Konturek SJ, Tasler J. Pancreatic polypeptide and vagal stimulation of gastric and pancreatic secretion in dogs. Hepatogastroenterology 1981; 28: 206-9.

14 Liddle RA, Goldfine ID, Rosen MS, Taplitz R, Williams JA. Cholecystokinin bioactivity in human plasma: molecular forms, responses to feeding, and relationship to gallbladder contraction. J Clin Invest 1985; 75: 1144 52.

15 Rovati AL, Casula PL, Dare G. Attivita antisecretiva di alcuni nuovi compositi privi di attivita anticholinergica. Minerva Med 1967; 58: 3651.

16 Stubbs RS, Stabile BE. Role of cholecystokinin in pancreatic exocrine response to intraluminal amino acids and fat. Am J Physiol 1985; 248: G347-53.

17 Lotti VJ, Pendleton RG, Gould RJ, Hanson HM, Chang RSL, Clineschmidt BV. In vivo pharmacology of L-364,718, a new potent nonpeptide peripheral cholecystokinin antagonist. J Pharmacol Exp Ther 1987; 241: 103-9.

18 Pendleton RG, Bendesky RJ, Schaffer L, Nolan TE, Gould RJ, Clineschmidt BV. Roles of endogenous cholecystokinin in biliary, pancreatic and gastric function: Studies with L-364,718, a specific cholecysto- 
kinin receptor antagonist. J Pharmacol Exp Ther 1987; 241: $110-6$.

19 Konturek SJ. Current concepts of neurohormonal control of pancreatic secretion. Ir J Med Sci 1978; 147: $1-12$.

20 White TT, Lundh G, Magee DF. Evidence for the existence of a gastro-pancreatic reflex. Am J Physiol 1960; 198: 725-8.

21 Debas HT, Yamagishi T. Evidence for pyloropancreatic reflex for pancreatic exocrine secretion. Am J Physiol 1978; 234: E468-71.

22 Solomon TE, Grossman MI. Effect of atropine and vagotomy on response of transplanted pancreas. Am J Physiol 1979; 236: E186-90.

23 Singer MV, Solomon TE, Grossman MI. Effect of atropine on secretion from the intact and transplanted pancreas in the dog. Am J Physiol 1980; 238: G18-22.

24 Singer MV. Latency of pancreatic fluid secretory response to intestinal stimulants in the dog. $J$ Physiol (Lond) 1983; 339: 75-85.

25 Debas HT, Konturek SJ, Grossman MI. Effect of extragastric and truncal vagotomy on pancreatic secretion in dog. Am J Physiol 1975; 228: 1172-7.

26 Konturek SJ, Solomon TE. Does gastrin play a role in cephalic phase of pancreatic secretion? Dig Dis Sci 1874; 29: 44S.

27 Soll A, Amirian D, Park J. Cholecystokinin potently releases somatostatin from canine fundic mucosal cells in short term culture. Am J Physiol 1985; 248: G569753. 